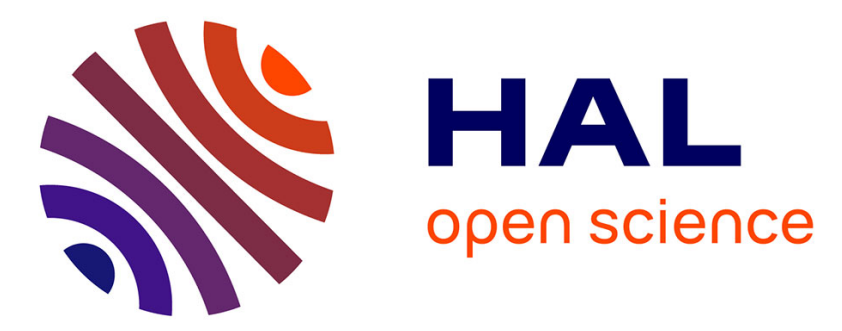

\title{
Addition of carbon nucleophiles to hemiaminals promoted by a Lewis acidic polyoxotungstate
}

Wen-Jing Xuan, Candice Botuha, Bernold Hasenknopf, Serge Thorimbert

\section{To cite this version:}

Wen-Jing Xuan, Candice Botuha, Bernold Hasenknopf, Serge Thorimbert. Addition of carbon nucleophiles to hemiaminals promoted by a Lewis acidic polyoxotungstate. Organic Chemistry Frontiers, 2014, 1 (9), pp.1091 - 1095. 10.1039/C4QO00193A . hal-01528776

\section{HAL Id: hal-01528776 https://hal.sorbonne-universite.fr/hal-01528776}

Submitted on 29 May 2017

HAL is a multi-disciplinary open access archive for the deposit and dissemination of scientific research documents, whether they are published or not. The documents may come from teaching and research institutions in France or abroad, or from public or private research centers.
L'archive ouverte pluridisciplinaire HAL, est destinée au dépôt et à la diffusion de documents scientifiques de niveau recherche, publiés ou non, émanant des établissements d'enseignement et de recherche français ou étrangers, des laboratoires publics ou privés. 
DOI: $10.1039 / \mathrm{c4q000193a}$

\title{
Addition of carbon nucleophiles to hemiaminals promoted by a Lewis acidic polyoxotungstate
}

\author{
Wen-Jing Xuan, Candice Botuha, Bernold Hasenknopf and Serge Thorimbert*
}

a) Sorbonne Universités, UPMC Univ Paris 06. UMR 8232, Institut Parisien de Chimie Moléculaire. F-75005 Paris, France.

b) CNRS, UMR 8232, IPCM, F-75005 Paris, France.

Abstract : A Lewis acidic hafnium(IV) ion incorporated in a polyoxotungstate (POM/Hf) was successfully employed as recoverable catalyst in the nucleophilic addition of carbon nucleophiles, such as silyl enol ethers, silyl ketene acetals, $\beta$ diketones and $\beta$-diketoesters, to unprotected hydroxy aminal at room temperature. The corresponding $\alpha$-substituted heterocycles were obtained in good yields and the recovered POM catalyst could be reused up to three times without significant loss of activity.

In the synthesis of nitrogen-containing heterocycles, $N$-acyliminium ions have been widely used as efficient electrophiles. ${ }^{1}$ Most often these stabilized ionic intermediates are generated from precursors such as amino nitrile, N,O acetals in acidic medium in the presence of stoichiometric quantities of Brønsted acids or traditional Lewis acids, such as $\mathrm{BF}_{3} \cdot \mathrm{OEt}_{2}, \mathrm{TiCl}_{4}, \mathrm{SnCl}_{4}, \mathrm{InCl}_{3}, \mathrm{NbCl}_{5}$ and $\left.\mathrm{Zn}_{(\mathrm{OTf}}\right)_{2}$, which are environmentally harmful. ${ }^{2,3,4}$ More recently, catalytic versions have been reported that take advantage of the Lewis acidic properties of lanthanides triflates ${ }^{5}$ or $\mathrm{N}$-trimethyl silyl-bis-(trifluoromethanesulfonyl)imide derivatives $\left(\mathrm{HNTf}_{2} \text {; Zn }\left(\mathrm{NTf}_{2}\right)_{2}\right)^{6}$ or Brønsted organocatalysts. ${ }^{7}$ Even if those conditions are efficient for synthetic purpose, ${ }^{8}$ the need of alkoxy- or acetoxy- aminals lengthen the overall process. Indeed, from the point of view of atom economy and environmental reasons, the direct use of unprotected hemiaminals, which are more easily available, would be better. ${ }^{9}$ Some results in this field, including those with activated benzylic alcohols have been reported ${ }^{9 \mathrm{~d}}$ but to our knowledge, none of them reports the recovery of the catalyst.

Polyoxometalates (POMs) as rapidly expanding green catalysts, are widely used in oxidation and acid catalyzed transformations. ${ }^{10}$ In a previous work, organic soluble Lanthanide complexes of POMs were synthesized by grafting Lewis acidic cations $\left(\mathrm{Y}^{3+}, \mathrm{Yb}^{3+}, \mathrm{La}^{3+}\right.$, $\left.\mathrm{Hf}^{3+}, \mathrm{Sc}^{3+} \ldots\right)$ onto monolacunary Dawson polyoxotungstates $\left[\mathrm{P}_{2} \mathrm{~W}_{17} \mathrm{O}_{61}\right]^{10-}$ and used as Lewis acid catalysts for Mannich type reactions. ${ }^{11}$ We demonstrated that the coordination between the metal atoms and water molecules allows an indirect Brønsted acidity useful to catalyze Mukaiyama-aldol reactions. ${ }^{12}$ In order to expand the application of those catalysts, the hafnium(IV) complex TBA ${ }_{5} \mathrm{~K}\left[\alpha_{1} \mathrm{Hf}\left(\mathrm{H}_{2} \mathrm{O}\right)_{4} \mathrm{P}_{2} \mathrm{~W}_{17} \mathrm{O}_{61}\right]$ (POM/Hf) (scheme 1) was selected as a representative species and used in the challenging nucleophilic addition reactions to in situ generated cyclic $N$-acyliminium ions from 5- $N$-Boc-2-hydroxypyrrolidine 1a and $N$-Boc2-hydroxypiperidine $\mathbf{1 b}$ respectively.

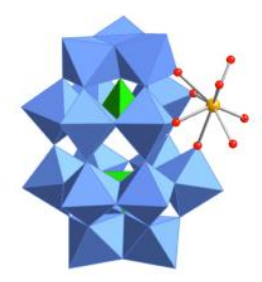

Scheme 1 Representation of the anion of $\mathrm{TBA}_{5} \mathrm{~K}\left[\alpha_{1}-\mathrm{Hf}\left(\mathrm{H}_{2} \mathrm{O}\right)_{4} \mathrm{P}_{2} \mathrm{~W}_{17} \mathrm{O}_{61}\right]$. The phosphotungstic framework is shown as coordination polyhedra (blue $\mathrm{W}$, green $\mathrm{P}$ ). The $\mathrm{Hf}^{4+}$ ion (yellow) is coordinated to four terminal oxo ligands and four water molecules (red).

We report herein our results concerning the POM/Hf-mediated nucleophilic additions of silyl enol ethers, ketene-acetals and activated methylene $\mathrm{C}$-nucleophiles to hemiaminals that provide an easy access to substituted pyrrolidines and piperidines derivatives via cyclic $N$-acyliminium ions at room temperature.

We initially chose to examine the addition of 1-Phenyl-1-trimethylsiloxyethylene 2a to $N$-Boc-2-hydroxypyrrolidine 1a as a model reaction in the presence of $10 \mathrm{~mol} \%$ catalyst at room temperature in $\mathrm{CH}_{3} \mathrm{CN}$. The expected product 3a was isolated in $69 \%$ yield after 20 min. (Table 1, entry 2). 
Table 1 Optimization of the amount of catalyst for the reaction between $N$-Boc-2-hydroxypyrrolidine 1a and 1-Phenyl-1trimethyl-siloxyethylene $\mathbf{2 a}$.

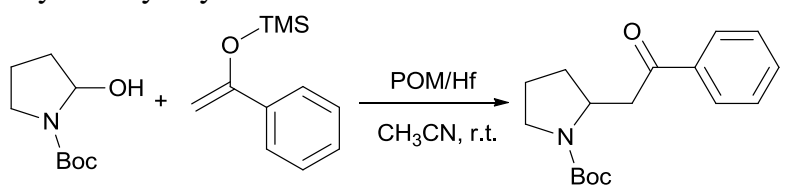

$1 \mathbf{a}$

$2 \mathbf{a}(1$ eq.)

$3 \mathbf{a}$

\begin{tabular}{|c|c|c|c|}
\hline Entry & POM/Hf (mol\%) & Time & Yield $(\%)$ \\
\hline 1 & - & $24 \mathrm{~h}$ & - \\
\hline 2 & 10 & $20 \min$ & 69 \\
\hline 3 & 1 & $1 \mathrm{~h}$ & 72 \\
\hline 5 & 0.25 & $17 \mathrm{~h}$ & 80 \\
\hline
\end{tabular}

It is possible to decrease the loading of catalyst down to $0.25 \mathrm{~mol} \%$ albeit the reaction time should be increased up to $17 \mathrm{~h}$ to achieve a similar yield (Table 1, entry 4). However, the amount of $1 \mathrm{~mol} \%$ of POM/Hf was chosen to extend the scope of the nucleophilic addition as well as the use of $N$-Boc-2-hydroxypiperidine $\mathbf{1 b}$ as electrophile..

Unfortunately, the reaction of 1-Phenyl-1-trimethylsiloxy-ethylene $\mathbf{2 a}$ with $N$-Boc-2-hydroxypiperidine $\mathbf{1 b}$ was not as efficient as for $\mathbf{1 a}$. Indeed, in the previous conditions a low yield of the expected product $\mathbf{3 b}$ together with a total consumption of the starting material was observed (Table 2, entry 2), a pattern that results from the elimination of water from the corresponding iminium. Actually, the in-situ formed $\mathrm{N}$-acyliminium intermediate resulting from the interaction of the $N$-Boc-2-hydroxypiperidine 1b and POM/Hf can lead to the relatively stable enecarbamate by-product $\mathbf{4 b}$, or can undergo self-condensation to further form the "dimeric" enecarbamate $\mathbf{5 b}$ which were proved to be inert to the nucleophile $\mathbf{2 a}$. $^{13,14}$ Both forms of enecarbamate cause the competitive loss of starting materials, which can explain the relatively low yield for all the 2-substituted $N$-piperidines.

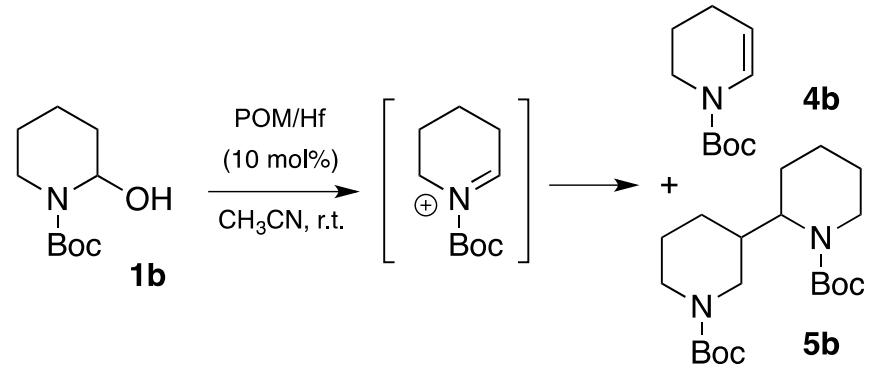

Scheme 2 Competitive elimination and dimerization of $\mathrm{N}$-Boc-2-hydroxypiperidine $\mathbf{1 b}$ via $\mathrm{N}$-acyliminium.

Thereafter, the scope of the reaction was investigated with different substrates N-Boc pyrrolidine 1a and N-Boc piperidine $\mathbf{1 b}$ and a series of nucleophiles such as silyl enol ethers or ketene-acetals. The 1-(trimethylsiloxy)-cyclohexene $\mathbf{2 c}$ acts as a good nucleophile with $1 \mathrm{a}$ and gives the corresponding 2-substituted $N$-Boc pyrrolidine 3e, in $63 \%$ yield after $4 \mathrm{~h}$. Interestingly, an excellent yield of $98 \%$ as a 70:30 mixtures of diastereomers could be obtained by the used of 10 mol \% of catalyst (Table 2, entry 5). Both 1- and 2-(trimethylsilyloxy) butadiene 2d and 2e reacted moderately with pyrrolidine 1a (Table 2, entries 7 and 9).

Attempts to employ methyl trimethylsilyl dimethylketene acetal $\mathbf{2 b}$ and 1-(trimethylsiloxy)-cyclohexene $\mathbf{2 c}$ as nucleophiles with $N$-Boc-2-hydroxypiperidine $\mathbf{1 b}$ failed, which might be attributed to the relative steric hindrance of the secondary or tertiary reactive $\mathrm{C}$-atom whereas the less substituted nucleophiles $\mathbf{2 d - e}$ reacted in low yields. The competitive elimination of water on $\mathbf{1 b}$ (vide supra) simultaneously to the partial hydrolysis of the nucleophiles should be responsible of these unproductive results. In conclusion, our investigation on the addition of trimethylsilyl enol ethers to the 5-membered $\mathrm{N}$-acyliminium precursor 1a under Lewis acidic POM/Hf revealed that moderate to high yields of the corresponding 2-substituted $N$-Boc pyrrolidines were obtained. Lower yields were observed for the reaction between the same nucleophiles and the 6-membered precursor $\mathbf{1 b}$. 
Table 2. POM-catalyzed Reaction with Silylenol Ethers 2.

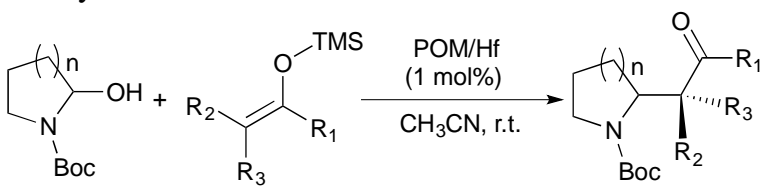

1a, 1 ba-e (1 eq.) $\quad 3 a-j$

\begin{tabular}{|c|c|c|c|c|c|}
\hline Entry & 1 & Nucleophile & Time (h) & Product & $\begin{array}{c}\text { Yield } \\
(\%)\end{array}$ \\
\hline 1 & $1 \mathbf{a}$ & & 1 & 3a & 72 \\
\hline 2 & $1 b$ & 20 & 0.3 & $3 \mathbf{b}$ & 16 \\
\hline 3 & $1 \mathbf{a}$ & & 18 & $3 c$ & $58^{\mathrm{a}}$ \\
\hline 4 & $1 b$ & 2b & 16 & 3d & - \\
\hline 5 & $1 \mathrm{a}$ & & 4 & $3 \mathbf{e}$ & $63^{\mathrm{b}}, 98^{\mathrm{c}}$ \\
\hline 6 & $1 b$ & 20 & 4 & $3 f$ & - \\
\hline 7 & $1 \mathrm{a}$ & & 24 & $3 g$ & $69^{\mathrm{d}}, 62^{\mathrm{d}}$ \\
\hline 8 & $1 \mathrm{~b}$ & $2 d$ & 1.5 & 3h & $24^{\mathrm{e}}$ \\
\hline 9 & $1 \mathrm{a}$ & & 4 & $3 \mathbf{i}$ & $45^{\mathrm{a}}$ \\
\hline 10 & $1 \mathrm{~b}$ & 20 & 4 & $\mathbf{3 j}$ & $10^{\mathrm{a}}$ \\
\hline
\end{tabular}

${ }^{\text {a }} 10 \mathrm{~mol} \%$ catalyst was used. ${ }^{\mathrm{b}}$ Diastereomeric ratio of $\mathbf{3 e}(70: 30)$. ${ }^{\mathrm{c}}$ After $18 \mathrm{~min}$. with 10 mol\% catalyst. ${ }^{\mathrm{d}}$ After $100 \mathrm{~min}$. with 10 mol\% cat. ${ }^{\text {e }} 4$ mol\% catalyst was used.

To further expand the scope of the reaction, the use of 1,3-dicarbonyl compounds 6 as nucleophiles was also investigated. Such enolizable C-nucleophiles are expected to react smoothly in such slightly acidic conditions. In the presence of POM/Hf, they provided the corresponding 2-substituted pyrrolidine adduct 7 in moderate to good yields as illustrated by the representative examples in Table 3. Acyclic diketones or keto esters reacted with electrophile 1a in yields ranging from 49 to $64 \%$ (Table 3 entries 1-6). Excellent yields were achieved in the reactions with 1,3-cyclopentanedione 6e or 1,3-cyclohexanedione 6f. The 2substituted $N$-Boc-pyrrolidines $7 \mathbf{i}$ and $7 \mathbf{k}$ were isolated in 96 and $85 \%$ yields respectively with 1 mol\% of POM/Hf as catalyst (Table 3, entries 9 and 11). The desired products 7i-k exist mainly in their corresponding enolic form as indicated from the inspection of the corresponding ${ }^{1} \mathrm{H}$ and ${ }^{13} \mathrm{C}$ NMR spectra (see SI). The products $\mathbf{7 c}, \mathbf{7 e}$ and $\mathbf{7 g}$ were formed as difficultly separable mixture of diastereoisomers. While the purification of $\mathbf{7 d}$ allowed its isolation as a single, analytically pure diastereomer, $\mathbf{7 h}$ and $\mathbf{7 l}$ could not be obtained as pure products. Besides, the attempt to employ diethyl malonate as nucleophile failed so far. As previously observed with silylenol ethers as nucleophyles, lower yields were noticed with hydroxypiperidine 1b in comparison to hydroxypyrrolidine 1a (Table 3, compare entries 1,3,5,9 vs 2,4,6,10). The lower reactivity of the 6-membered iminium in comparison to the 5-membered one, should be responsible for the presence of elimination products. ${ }^{13-16}$ 
Table 3. POM-catalyzed Reaction with 1,3-dicarbonyls ( $\beta$-diketones or $\beta$-ketoesters).

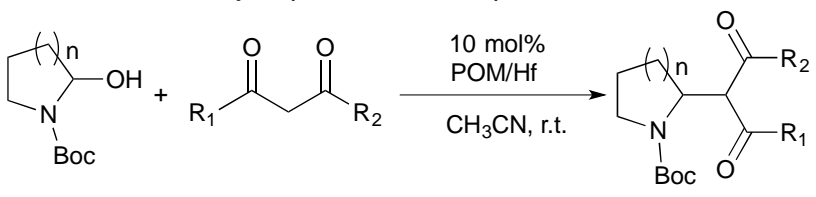

1a, $1 \mathrm{~b}$

6a-f

7a-I

\begin{tabular}{|c|c|c|c|c|c|}
\hline Entry & 1 & Nucleophile & $\begin{array}{l}\text { Time } \\
\text { (h) }\end{array}$ & Product & $\begin{array}{l}\text { Yielc } \\
(\%)\end{array}$ \\
\hline 1 & 1a & & 3 & $7 a$ & 63 \\
\hline 2 & $1 b$ & $6 a$ & 1 & $7 b$ & 57 \\
\hline 3 & 1a & & 20 & $7 c$ & 64 \\
\hline 4 & $1 \mathrm{~b}$ & $6 \mathrm{~b}$ & 39 & $7 d$ & $8^{\mathrm{a}}$ \\
\hline 5 & 1a & & 6.5 & $7 e$ & 55 \\
\hline 6 & $1 \mathrm{~b}$ & $6 c$ & 22 & $7 f$ & 35 \\
\hline 7 & 1a & & 5.5 & $7 \mathrm{~g}$ & 49 \\
\hline 8 & $1 b$ & $6 d$ & 5.5 & $7 \mathrm{~h}$ & - \\
\hline 9 & 1a & & 5.5 & $7 \mathbf{i}$ & $96^{\mathrm{b}}$ \\
\hline 10 & $1 \mathrm{~b}$ & $6 e$ & 4 & $7 \mathbf{j}$ & $83^{b}$ \\
\hline 11 & $1 \mathrm{a}$ & & 2 & $7 \mathrm{k}$ & $85^{\mathrm{b}}$ \\
\hline 12 & $1 b$ & $6 f$ & 2 & 71 & - \\
\hline
\end{tabular}

In our previous work, the POM/Hf has been used for its Lewis acidity in Mannich reactions and its induced Brønsted acidity for Mukaiyama-aldol reactions. We thus decided to explore the acidity involved in the present activation of hemiaminals 1a,b.

For that purpose, pyridine and 2,6-di-tert-butylpyridine were used as additives during the POM/Hf catalyzed nucleophilic addition. ${ }^{17}$ Both bases are strong enough to capture protons and should inhibit any Brønsted acid-catalyzed reaction. While pyridine can also bind to metal centers, thus inhibiting strongly Lewis acid-catalyzed reactions, 2,6-di-tert-butylpyridine is highly hindered and should less coordinate to the Lewis acidic Hafnium ion located in our bulky POM. Therefore its effect on Lewis acid catalysis is expected to be weak. In our experiments, when pyridine $(20 \mathrm{~mol} \%)$ was added, the reaction between 1-phenylvinyl trimethylsilyl ether 2a (5 equiv.) and $N$-Boc-2-hydroxypyrrolidine 1a was totally halted, while no influence was observed in the presence of 2,6-di-tert-butylpyridine (Table 4). We thus conclude that the reaction is catalyzed in a Lewis acidic manner by the coordination of the substrates $\mathbf{1 a}, \mathbf{b}$ to the $\mathrm{Hf}^{4+}$ ion incorporated in the POM. 
Table 4. Mechanism Consideration, Inhibition with Pyridine Derivatives as Additive

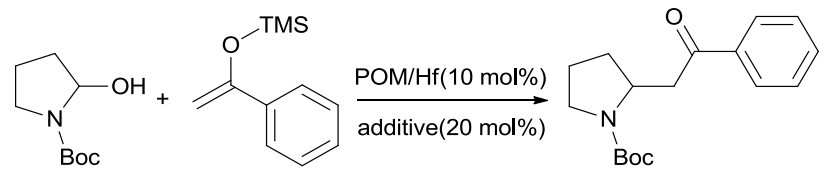

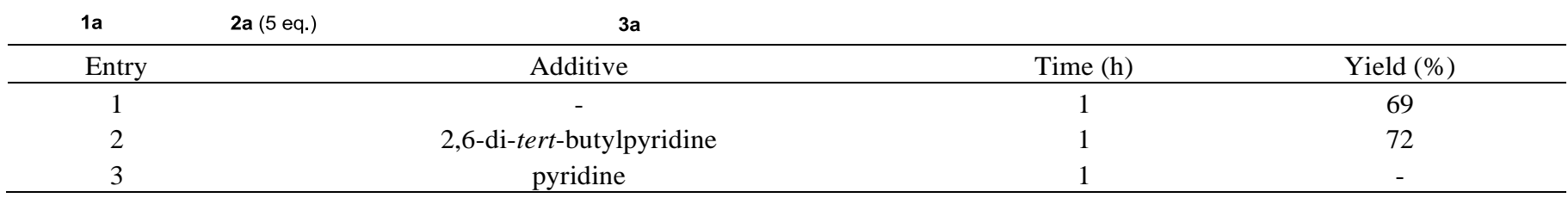

We also examined the possible recovery of our catalyst. Due to the specific solubility of POMs, the catalyst should be easily recovered. Indeed, at the end of the reaction the addition of a solvent mixture of acetone/ethanol/diethyl ether (1/1/20) resulted in the precipitation of the POM/Hf as a white powder (with a recovery of $>95 \%$ yield). In this study, the recyclability of catalyst has been tested on the $1 \mathrm{~mol} \%$ scale, and its purity was checked by ${ }^{31} \mathrm{P}$ NMR after each round. The catalyst can be reused at least for three times without losing its reactivity. Slow decrease was then observed due to the few mg handled as well as probable slow decomposition and/or dimerization of the catalyst as time going. ${ }^{18}$

Table 5 Recyclability of the Catalyst.<smiles>CC(=O)OC(=O)N1CCCC1[OH2+]</smiles>

$1 \mathrm{a}$<smiles>C=C(O[As])c1ccccc1</smiles>

2a (1 eq.)

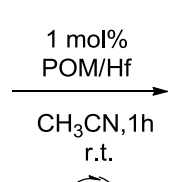

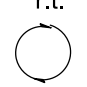

$\mathrm{Me}_{2} \mathrm{CO}: \mathrm{EtOH}: \mathrm{Et}_{2} \mathrm{O}=1: 1: 20$

recycled catalyst

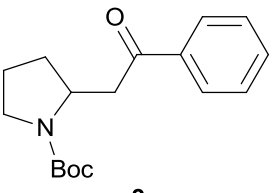

$3 a$

\begin{tabular}{ccccc}
\multicolumn{2}{c}{ recycled catalyst } & 3 & 4 \\
\hline Cycle & 1 & 2 & 69 & 49 \\
\hline Yield $(\%)$ & 72 & 74 & 69 \\
\hline
\end{tabular}

Finally, we also examined the addition of allyltrimethylsilane to the reagent 1a. By using 20 mol\% of POM/Hf catalyst, a $17 \%$ yield of the expected 2-allyl carbamate product 8a was obtained after $120 \mathrm{~h}$. Although the yield is relatively low, this is the first time such kind of polyoxometalate complex (POM/Hf) allows the nucleophilic addition of allyltrimethylsilane onto emiaminal via the in situ formation of $\mathrm{N}$-acyliminium ions.

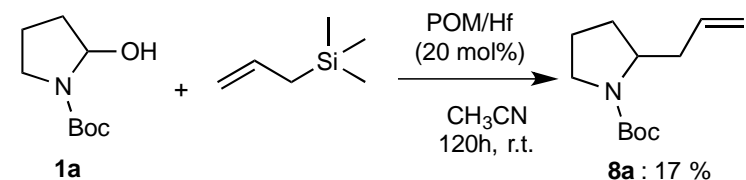

Scheme 3 : Reaction with allyl silane

In summary, we used a Hafnium containing Dawson polyoxometalate as soluble catalyst for the carbon nucleophilic addition of silyl ether and methylene activated pro-nucleophiles to cyclic hemiaminals. The in-situ formed $N$-acyliminium ions reacted smoothly at room temperature giving the desired pyrrolidine and piperidine products in moderate to good yields. The POM/Hf has been proved to catalyze the reaction in a Lewis acidic pathway. It can be easily precipitated and removed taking advantage of its specific solubility. Recycling of the catalyst is possible for a limited number of cycles. Studies are still underway for its further application in other organic reactions and its asymmetric versions. 


\section{Acknowledgements}

We thank the Université P. et M. Curie (UPMC) and CNRS for funding. The Fédération de Recherche (FR2769) provided technical access for analysis. M. Forêt Jacquard kindly tested the reproducibility of the reactions. W.J.X. acknowledges the China Scholarship Council (CSC) for a PhD fellowship.

\section{Notes and references}

1 Selected reviews : (a) B.E. Maryanoff, H.-C. Zhang, J. H. Cohen, I. J. Turchi and C. A. Maryanoff, Chem. Rev., 2004, 104, 1431. (b) A. Yaziri and S. G. Pyne Synthesis, 2009, 339. (c) A. Yaziri and S. G. Pyne, Synthesis, 2009, 513. (d) N. R. Candeias, L. C. Branco, P. M. P. Gois, C. A. M. Afonso and A. F. Trinidade, Chem. Rev., 2009, 109, 2703. (e) U. Martinez-Estibalez, A. Gomez-SanJuan, O. Garceia-Calvo, E. Aranzamendi, E. Lete and N. Sotomayor, Eur. J. Org. Chem., 2011, 3610. (f) P.-Q. Huang, Synlett, 2006, 1133-1149. P. M. Weintraub, J. S. Sabol, J. M. Kane and D. R. Borcherding, Tetrahedron, 2003, 59, 2953-2989. (g) D. Enders and J. P. Shilvock, Chem. Soc. Rev., 2000, $29,359$.

2 (a) C. J. Li, Chem. Rev., 1993, 93, 2023.

3 (a) D. Russowsky, R. Z. Petersen, M. N. Godoi and R. A. Pilli, Tetrahedron Lett., 2000, 41, 9939. (b) C. K. Z. Andrade and R. A. F. Matos, Synlett., 2003, 1189.

4 R. A. Pilli and L. G. Robello, Synlett. 2005, 2297.

5 (a) S. Kobayashi, M. Sugiura, H. Kitagawa and W. W.-L. Lam, Chem. Rev., 2002, 102, 2227. (b) S. Kobayashi, Eur. J. Org. Chem., 1999, 15. (c) for a recent application of $\mathrm{Bi}(\mathrm{OTf})_{3}$ see A. E. Schneider, T. Beisel, A. Shemet and G. Manolikakes, Org. Biomol. Chem., $2014,12,2356$.

6 (a) H. Yamamoto, Proc. Jpn. Acad. Ser. B., 2008, 84, 134-146. (b) B. Mathieu and L. Ghosez, Tetrahedron Lett., 1997, 38, 5497. (c) R. Ben Othman, T. Bousquet, M. Othman and V. Dalla, Org. Lett., 2005, 7, 5335.

7 (a) Y. S. Lee, Md. M. Alam and R. S. Keri, Chem. Asian J., 2013, 8, 2906. (b) T. Akiyama, J. Itoh and K. Fuchibe, Adv. Synth. Catal., 2006, 348, 999. (c) see a special issue of Chem. Rev., 2007, $107, \mathrm{n}^{\circ} 12$.

8 Selected examples (a) M. E. Muratore, C. A. Holloway, A. W. Pilling, R. I. Storer, G. Trevitt and D. J. Dixon, J. Am. Chem. Soc., 2009, 131, 10796. (d) A. C. Breman, J. Dijkink, J. H. van Maarseveen, S. S. Kinderman and H. Hiemstra J. Org. Chem., 2009, 74, 6327. (c) H. Sun, C. Martin, D. Kesselring, R. Keller and K. D. Moeller, J. Am. Chem. Soc., 2006, 128, 13761. (c) U. Albrecht, H. Armbrust, P. Langer, Synlett, 2004, 143. (d) J.-C. Adelbrecht, D. Craig, B. W. Dymock and S. Thorimbert, Synlett, 2000, 467. (e) J.-C. Adelbrecht, D. Craig and S. Thorimbert, Tetrahedron Lett., 2001, 42, 8369.

9 (a) N. S. Camilo and R. A. Pilli, Tetrahedron Lett., 2004, 45, 2821. (b) R. Ben Othman, R. Affani, M.-J. Tranchant, S. Antoniotti, V. Dalla and E. Dunach, Angew. Chem. Int. Ed., 2010, 49, 776. (c) for an original copper catalyzed version see S.-L. Shi, X.-F. Wei, Y. Shimizu and M. Kanai, J. Am. Chem. Soc., 2012, 134, 17019. (d) M. Hamon, N. Dickinson, A. Devineau, D. Bolien, M.-J. Tranchant, C. Taillier, I. Jabin, D. C. Harrowven, R. J. Whitby, A. Ganesan and V. Dalla, J. Org. Chem., 2014, 79, 1900. (e) M. Szostak, B. Sautier and D. J. Procter Chem. Commun., 2014, 50, 2518.

10 (a) M. Misono, Catal. Today, 2005, 100, 95. (b) "Applications of Polyoxometalates in Homogeneous Catalysis": R. Neumann in Polyoxometalate Molecular Science, Vol. 98; J. J. Borras-Almenar, E. Coronado, A. Müller, M. T. Pope, Eds.; Kluwer, Dordrecht, 2003 , p. 327. (c) "Heterogeneous Catalysis by Heteropoly Compounds", I. V. Kozhevnikov, ibid., p. 351. (d) X. Fang and C. L. Hill, Angew. Chem. Int. Ed., 2007, 46, 3877. (e) J. Geboers, S. Van de Vyver, K. Carpentier, K. de Blochouse, P. Jacobs and B. Sels, Chem. Commun., 2010, 46, 3577. see also (f) S. Luo, J. Li, H. Xu, L. Zhang and J. P. Cheng, Org. Lett., 2007, 9, 3675. (g) J. Li, S. Hu, S. Luo and J. P. Cheng, Eur. J. Org. Chem., 2009, 132. (h) A. E. Kuznetsov, Y. V. Geletii, C. L. Hill, K. Morokuma and D. G. Musaev, Inorg. Chem., 2009, 48, 1871. (i) A. Sartorel, M. Carraro, A. Bagno, G. Scorrano and M. Bonchio, Angew. Chem. Int. Ed., 2007, 119, 3319. (j) A. Sartorel, P. Miro, E. Salvadori, S. Romain, M. Carraro, G. Scorrano, M. Di Valentin, A. Llobet, C. Bo and M. Bonchio, J. Am. Chem. Soc., 2009, 131, 16051. (k) B. P. Burton-Pye and L. C. Francesconi, Dalton Trans., 2011, 40, 4421. (1) M. R. Antonio, J. Jing, B. P. Burton-Pye and L. C. Francesconi, Dalton Trans., $2010,39,7980$.

11 (a) C. Boglio, G. Lenoble, C. Duhayon, B. Hasenknopf, R. Thouvenot, C. Zhang, R. C. Howell, B. P. Burton-Pye, L. C. Francesconi, E. Lacôte, S. Thorimbert, M. Malacria, C. Afonso and J.-C. Tabet, Inorg. Chem., 2006, 45, 1389. (b) C. Boglio, G. Lemière, B. Hasenknopf, S. Thorimbert, E. Lacôte. and M. Malacria, M. Angew. Chem. Int. Ed., 2006, 45, 3324; c) C. Boglio, K. Micoine, P. Rémy, B. Hasenknopf, S. Thorimbert, E. Lacôte, M. Malacria, C. Alfonso and J.-C. Tabet, Chem. Eur. J., 2007, 13, 5426. (d) M. Bosco, S. Rat, N. Dupré, B. Hasenknopf, E. Lacôte, M. Malacria, P. Rémy, J. Kovensky, S. Thorimbert and A. Wadouachi, ChemSusChem, 2010, 3, 1249. see also some other pioneer references : (e) Y. Kikukawa, S. Yamaguchi, K. Tsuchida, Y. Nakagawa, K. Uehara, K. Yamaguchi and N. Mizuno, J. Am. Chem. Soc., 2008, 130, 5472. (f) X. Zhang, J. Li, Y. Chen, J. Wang, L. Feng, X. Wang and F. Cao Energy Fuels, 2009 23, 4640. (g) J. Li, X. Zhang, W. Zhu and F. Cao, ChemSusChem, 2009, 2, 177

12 (a) E. Derat, E. Lacôte, B. Hasenknopf, S. Thorimbert and M. Malacria, J. Phys. Chem. A, 2008, 112, 13002. (b) N. Dupré, P. Rémy, Pauline, K. Micoine, C. Boglio, S. Thorimbert, E. Lacôte, B. Hasenknopf and M. Malacria, Chem. Eur. J., 2010, 16, 7256.

13 D. F. Oliveira, P. C. M. L. Miranda and R. D. C. Carlos, J. Org. Chem., 1999, 64, 6646.

14 (a) A. R. Pinder, Nat. Prod. Rep., 1989, 515. (b) G. J. Koomen and M. J. Wanner, J. Org. Chem., 1996, $61,5581$.

15 R. A. Pilli, L. G. Robello, N. S. Camilo, J. Dupont, A. A. Moreira Lapis and B. A. da Silveira Neto, Tetrahedron Lett., $2006,47,1669$. 
16 (a) R. A. Pilli, M. A. Böckelmann and C. F. Alves, J. Braz. Chem., Soc. 2001, 12, 634. (b) M. G. M. D’Oca, L. A. B. Moraes, R. A. Pilli and M. N. J. Eberlin. J. Org. Chem., 2001, 66, 3854.

17 (a) H. C. Brown and R. B. Johannesen, J. Am. Chem. Soc., 1953, 75, 16. (b) A. Corma, Chem. Rev., 1995, 95, 559. (c) Y. Kikukawa, S. Yamaguchi, Y. Nakagawa, K. Uehara, S. Uchida, K. Yamaguchi, N. Mizuno, J. Am. Chem. Soc., 2008, 130, 15872.

18 (a) M. N. Sokolov, N. V. Izarova, E. V. Peresypkina, D. A. Mainichev and V. P. Fedin, Inorg. Chim. Acta, 2009, 362, 3756. (b) Y. Saku, Y. Sakai, K. Nomiya, Inorg. Chim. Acta, 2010, 363, 967. 